\title{
Predicting critical duration and reversibility of damage in acute mesenteric ischemia: An experimental study
}

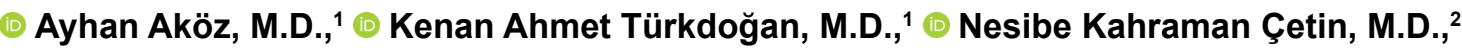

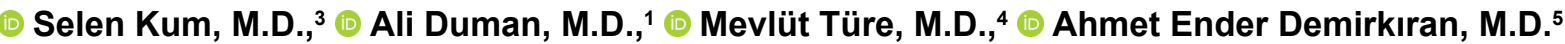

\author{
${ }^{1}$ Department of Emergency Medicine, Adnan Menderes University Faculty of Medicine, Aydın-Turkey \\ ${ }^{2}$ Department of Pathology, Adnan Menderes University Faculty of Medicine, Aydın-Turkey \\ ${ }^{3}$ Department of Histology, Adnan Menderes University Faculty of Medicine, Aydın-Turkey \\ ${ }^{4}$ Department of Biostatistics, Adnan Menderes University Faculty of Medicine, Aydın-Turkey \\ ${ }^{5}$ Department of General Surgery, Adnan Menderes University Faculty of Medicine, Aydın-Turkey
}

\begin{abstract}
BACKGROUND: The objective of the current study was to investigate the value of the ischemic biomarkers endothelial cell-specific molecule-I (endocan) and signal peptide-CUB-EGF domain-containing protein-I (SCUBE-I) in the diagnosis and assessment of earlystage and irreversible damage in acute mesenteric ischemia.

METHODS: An experimental mesenteric ischemia reperfusion model was designed using 54 rats. Nine groups were created: Three

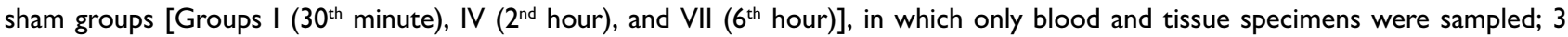
ischemia groups [Groups II ( $30^{\text {th }}$ minute), V ( $2^{\text {nd }}$ hour), and VIII ( $6^{\text {th }}$ hour $)$ ], in which blood and tissue specimens were sampled after ligation of the superior mesenteric artery (SMA); and 3 reperfusion groups [Groups III $\left(30^{\text {th }}\right.$ minute), VI $\left(2^{\text {nd }}\right.$ hour), and IX ( $6^{\text {th }}$ hour $)$ ], in which blood and tissue specimens were sampled after declamping the SMA and reperfusion for I hour. SCUBE-I and endocan samples obtained from blood and tissue were examined histopathologically.
\end{abstract}

RESULTS: The SCUBE-I level was higher in the ischemia groups when compared with the sham groups $(p<0.05)$, and the endocan level was markedly different in the late ischemia ( $6^{\text {th }}$ hour) group. When these 2 markers were used together to assess irreversible mesenteric damage in the histopathological examination, the sensitivity in distinguishing between reversible or irreversible damage was $94.1 \%$ with a specificity of $73.7 \%$.

CONCLUSION: The elevation of SCUBE-I alone seems to be significant for predicting early mesenteric ischemia in laboratory rats. The combination of SCUBE-I and endocan may be useful to detect irreversible intestinal damage.

Keywords: Acute mesenteric ischemia; endocan; irreversibility; signal peptide-CUB-EGF domain-containing protein-I.

\section{INTRODUCTION}

Signal peptide-CUB-EGF domain-containing protein-I (SCUBE-I) is a novel cell surface protein that contains some molecules found in alpha-granules. ${ }^{[I]}$ It is translocated to the platelet surface after thrombin activation. The accumulation of SCUBE-I has been detected in advanced atherosclerotic lesions in humans. It is considered a new platelet endothelial adhesion molecule. In acute ischemic stroke and acute coro- nary syndrome, the mechanisms responsible for ischemic complications are platelet activation and aggregation. Dai et al. ${ }^{[2]}$ demonstrated that the SCUBE-I protein can be a good marker for acute thrombotic diseases. It is detectable within 6 hours of the onset of ischemic symptoms. Endothelial cellspecific molecule I (endocan) is a new biomarker of endothelial dysfunction. ${ }^{[3]}$ It is a soluble dermatan sulfate proteoglycan which is primarily secreted by vascular endothelial cells. ${ }^{[4]} \mathrm{En}$ docan plays a key role in the pathophysiology of endothelial

Cite this article as: Aköz A, Türkdoğan KA, Kahraman Çetin N, Kum S, Duman A, Türe M, et al. Predicting critical duration and reversibility of damage in acute mesenteric ischemia: An experimental study. Ulus Travma Acil Cerrahi Derg 2018;24:507-513.

Address for correspondence: Ayhan Aköz, M.D.

Adnan Menderes Üniversitesi Tıp Fakültesi, Acil Tıp Anabilim Dalı, 09100 Aydın, Turkey

Tel: +90256 - 2121850 E-mail: akozayhan@gmail.com

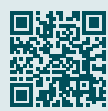

Ulus Travma Acil Cerrahi Derg 2018;24(6):507-5I3 DOI: 10.5505/tjtes.2018.69710 Submitted: 06.10.2017 Accepted: 21.06 .2018 Online: 08.1I.2018

Copyright 2018 Turkish Association of Trauma and Emergency Surgery 
dysfunction through its role in regulating physiological and pathological disorders. ${ }^{[5,6]}$

Although not common, acute mesenteric ischemia (AMI) is a lethal vascular emergency. If it is not treated effectively and promptly, it may cause ischemia, or even infarction. In the past decade, several large clinical series have reported high mortality rates of $30 \%$ to $65 \%{ }^{[7,8]}$ However, the optimal surgical management is still debated and deserves a clear recommendation based on a higher level of evidence. ${ }^{[9]}$ The ability to catch patients in the reversible period could increase the chances of success, and decrease mortality and morbidity.

The objective of the current study was to investigate the role of SCUBE-I and endocan, which can help make a diagnosis of ischemic events at different times, and to determine their power in distinguishing cases in which the damage is still reversible.

\section{MATERIALS AND METHODS}

\section{Animals}

A total of 54 female Wistar albino rats weighing between 220 and $250 \mathrm{~g}$ were used in the study. The research was conducted after receiving the approval of the animal ethics committee $(64583101 / 2016 / 006)$. The rats were housed at room temperature $\left(20 \pm 2^{\circ} \mathrm{C}\right)$ in a 12-hour daylight/dark environment, fed with standard food pellets, and allowed free access to water in individual cages.

\section{Experimental Protocol}

In all, 54 rats were used to design an experimental mesenteric ischemia reperfusion model. There were a total of 9 groups in the study. Three of these groups were sham groups [Groups I (30 $30^{\text {th }}$ minute), IV ( $2^{\text {nd }}$ hour), and VII ( $6^{\text {th }}$ hour $)$ ], from which only blood and tissue specimens were sampled. There were 3 ischemia groups [Groups II ( $30^{\text {th }}$ minute), V ( $2^{\text {nd }}$ hour), and VIII (6 $6^{\text {th }}$ hour)], in which blood and tissue specimens were sampled after ligation of the superior mesenteric artery (SMA). The remaining 3 groups were reperfusion groups [Groups III (30 ${ }^{\text {th }}$ minute), VI ( $2^{\text {nd }}$ hour), and IX (6 $6^{\text {th }}$ hour)], in which blood and tissue specimens were sampled after the SMA was declamped and reperfusion was induced for I hour. SCUBE-I and endocan retrieved from the blood samples and tissue samples were examined histopathologically.

Blood taken from the rats was centrifuged at $3500 \mathrm{rpm}$ for 10 minutes. The serum was collected and stored at $-80^{\circ} \mathrm{C}$ until further analysis.

\section{SCUBE-1}

An enzyme-linked immunosorbent assay (ELISA) kit (Sunlong Biotech Co., Ltd., Hangzhou, Zhejiang, China) designed for rats was used to determine the SCUBE-I level in the serum samples. The test results were calculated using a bio-ELISA reader (DARx800; Calabasas, USA) using a standard curve of $450 \mathrm{~nm}$. The limit to detect SCUBE-I was $0.01 \mathrm{ng} / \mathrm{mL}$, and the assay range was $0.1-7 \mathrm{ng} / \mathrm{mL}$. All of the procedures were performed according to the manufacturer's instructions.

\section{Endocan}

A commercial Sunlong Biotechrat ELISA kit, (Sunlong Biotech Co., Ltd., Hangzhou, Zhejiang, China) was used to determine the endocan ESM-I level in the serum samples. The test results were calculated using a bio-ELISA reader (DARx800; Calabasas, USA) using a standard curve of $450 \mathrm{~nm}$ and a limit of $0.01 \mathrm{ng} / \mathrm{mL}$. The assay range was $0.1-8 \mathrm{ng} / \mathrm{mL}$ for endocan ESM-I. All of the procedures were performed according to the manufacturer's instructions.

\section{Histopathological Evaluation}

For the histopathological examination, small intestine tissues were collected from all of the groups. They were fixed in $10 \%$ formaldehyde for $\mathbf{4 8}$ hours. Following fixation, ileum specimens were dehydrated in an ascending alcohol series (70, $90,96,100 \%)$, clarified with xylene and embedded in paraffin wax. Using a fully automatic microtome, 4-um sections were taken from the paraffin blocks and stained with hematoxylin and eosin. An experienced pathologist who was blind to the study groups used a light microscope for the histological examination of the preparates. All of the ileum tissue slides were examined at high magnification. Five different areas of the preparates from each group were evaluated at a magnification of $x \mid 00$. Mucosal injury was rated according to the classification systems described by Chiu et al.: ${ }^{[10]}$

Grade 0: Normal mucosa.

Grade 1: Subepithelial spaces at villus top due to capillary congestion

Grade 2: Expansion of subepithelial space with moderate lifting of epithelial layer

Grade 3: Massive epithelial detachment with occasional hemorrhage

Grade 4: Denuded villi with dilated capillaries

Grade 5: Disintegration of lamina propria, ulceration, and hemorrhage.

\section{Statistical Evaluation}

Descriptive statistics of the categorical variables were demonstrated in numbers (\%) and chi-square tests were used for the comparison of groups. The Kolmogorov-Smirnov test was used to test whether continuous variables were normally distributed. Since endocan and SCUBE-I were normally distributed, descriptive statistics were shown as the average $\pm S D$, and one-way analysis of variance (ANOVA) and independent samples t-tests were used to compare groups and time. The Bonferroni correction was used as a multiple comparison test. Descriptive statistics of i-scores not normally distributed were presented as the median (25\%-75\%), and the Mann-Whitney U-test and Kruskal-Wallis ANOVA tests were used to compare groups and time. 
Table I. Table of average endocan and SCUBE-I level of the study groups in terms of time

\begin{tabular}{llccc}
\hline & Time & $\begin{array}{c}\text { Sham } \\
\text { (Group I, IV, VII) }\end{array}$ & $\begin{array}{c}\text { Ischemia } \\
\text { (Group II, V, VIII) }\end{array}$ & $\begin{array}{c}\text { Reperfusion } \\
\text { (Group III, VI, IX) }\end{array}$ \\
\hline Endocan (Mean \pm SD) & $30^{\text {th }}$ minute & $2.12 \pm 0.19$ & $1.96 \pm 0.19$ & $2.15 \pm 0.20$ \\
& $2^{\text {nd }}$ hour & $1.99 \pm 0.18$ & $2.17 \pm 0.27$ & $2.24 \pm 0.17$ \\
& $6^{\text {th }}$ hour & $2.01 \pm 0.04$ & $2.49 \pm 0.33$ & $2.36 \pm 0.24$ \\
SCUBE I (Mean \pm SD) & $30^{\text {th }}$ minute & $1.37 \pm 0.20$ & $1.17 \pm 0.09$ & $1.49 \pm 0.23$ \\
& $2^{\text {nd }}$ hour & $1.25 \pm 0.16$ & $1.44 \pm 0.21$ & $1.71 \pm 0.40$ \\
& $6^{\text {th }}$ hour & $1.16 \pm 0.16$ & $1.62 \pm 0.16$ & $1.69 \pm 0.28$ \\
\hline \multirow{2}{*}{ Endocan: Endothelial cell-specific molecule-I; SCUBE-I: Signal peptide-CUB-EGF domain-containing protein I; SD: Standard deviation. }
\end{tabular}

Receiver operating characteristic (ROC) analysis and a classification and regression tree (CART) analysis were performed for SCUBE-I and endocan to be able to distinguish between normal-ischemia and reversibility-irreversibility. The sensitivity and specificity values were calculated according to the section points obtained.

The association between groups, ischemia-reperfusion data, and time variables were analyzed using multiple correspondence analysis. Pearson correlation analysis was conducted to determine the association between continuous variables.

\section{RESULTS}

Endocan and SCUBE-I levels were compared between the sham (Group I), ischemia (Group 2), and reperfusion (Group 3) groups at 30 minutes, 2 hours, and 6 hours (Table I and Fig. I). Endocan was not found to be statistically significant at minute $30(p=0.206)$; however, SCUBE-I was statistically significant $(p=0.028)$. This difference occurred between ischemia and reperfusion groups. While endocan levels at the second hour were not found to be significant $(p=0.131)$, SCUBE-I was significantly different $(p=0.036)$. This difference was seen between sham and reperfusion groups. Both endocan and SCUBE-I were found to be significantly different in groups at the 6th hour $(p=0.034, p=0.00 I$, respectively). While the significant difference in endocan was seen between sham and ischemia groups, the significance in SCUBE-I was observed between both sham-ischemia and sham-reperfusion groups.

The preparates were given ischemia scores between 0 and 5 histopathologically and grouped as normal or ischemic. Endocan and SCUBE-I levels were used to determine these groups. Both endocan and SCUBE-I were statistically significantly distinguishable between normal and ischemic preparates $(p=0.015, p=0.002$, respectively). ROC analysis

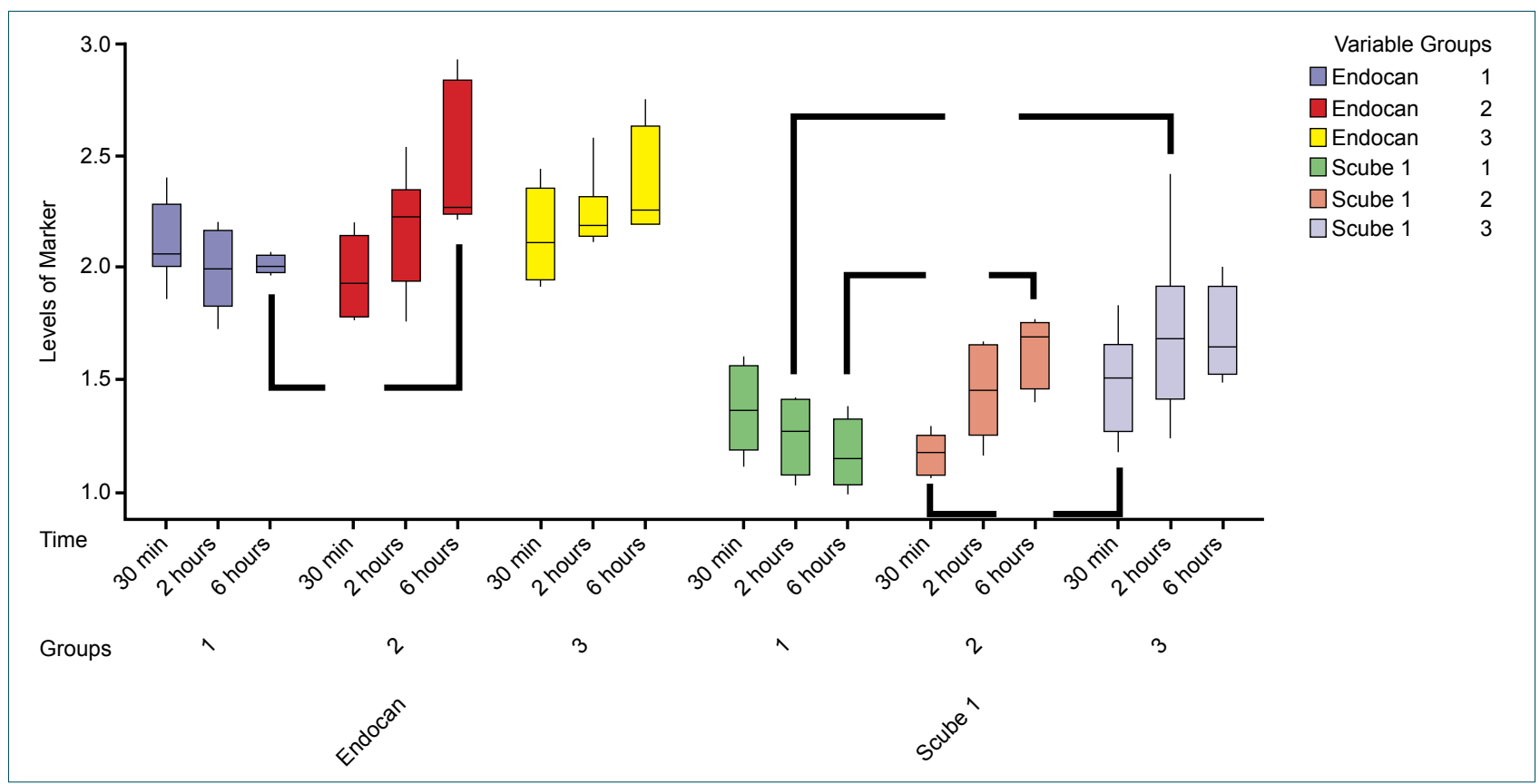

Figure 1. Average endocan and SCUBE-1 level of the study groups in terms of time. Endocan: Endothelial cell-specific molecule-1; SCUBE-1: Signal peptide-CUB-EGF domain-containing protein 1. 
Table 2. The average ischemia score of the ischemia and reperfusion groups at the $30^{\text {th }}$ minute, $2^{\text {nd }}$ hour, and $6^{\text {th }}$ hour

\begin{tabular}{lcc}
\hline Time & Ischemia & Reperfusion \\
\hline $30^{\text {th }}$ minute & $2(I-2.25)$ & $2(I-3)$ \\
$2^{\text {nd }}$ hour & $3.5(3-4.25)$ & $3.5(3-5)$ \\
$6^{\text {th }}$ hour & $5(4-5)$ & $5(4-5)$ \\
\hline
\end{tabular}

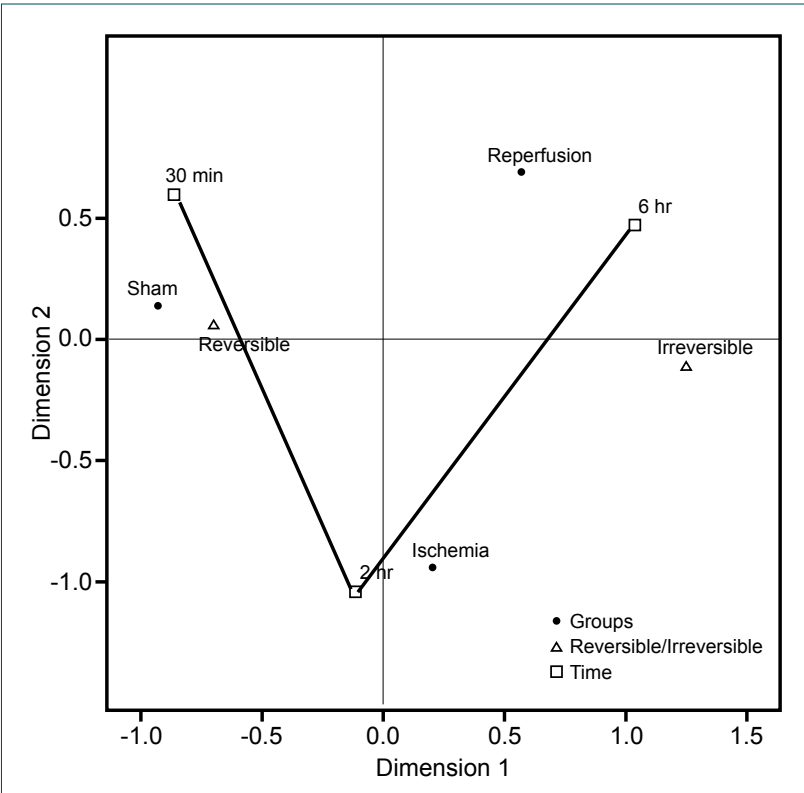

Figure 2. The distribution of preparates according to the results of multiple correspondence analysis. results indicated that an endocan cut-off value of 2.09 had a sensitivity of $75.7 \%$ and a specificity $75 \%$. A SCUBE-I cut-off value of 1.46 had a sensitivity of $64.9 \%$ and a specificity of 87.5\%. The positive likelihood ratio (+LR) and negative likelihood ratio $(-L R)$ values of endocan and SCUBE-I were 3.28 and 0.32 , and 5.20 and 0.40 , respectively.

When all of the preparates from the $30^{\text {th }}$ minute, $2^{\text {nd }}$ hour, and $6^{\text {th }}$ hour, which were given ischemia scores between 0 and 5 histopathologically, were compared in terms of ischemia and reperfusion groups, no statistically significant difference was found. When the ischemia scores of the ischemia group were compared in terms of time, there were significant differences between the $30^{\text {th }}$ minute and $2^{\text {nd }}$ hour, and the $30^{\text {th }}$ minute and $6^{\text {th }}$ hour $(p=0.002)$. When the ischemia scores of the reperfusion group were compared in terms of time, there were significant differences between the $30^{\text {th }}$ minute and $2^{\text {nd }}$ hour, and the $30^{\text {th }}$ minute and 6th hour $(p=0.002)$ (Table 2$)$.

According to multiple correspondence analysis results, there was a tendency to sham and reversible at $30^{\text {th }}$ minute, ischemia at the second hour, and reperfusion and irreversible ischemia at the sixth hour (Fig. 2).

Both ROC and CART analyses were conducted to find out the power of endocan and SCUBE-I in determining preparates grouped as reversible (Figs. 3a-c and $4 \mathrm{a}$ ) and irreversible (Fig. $4 \mathrm{~b}$ and $\mathrm{c}$ ) according to ischemia score.

According to ROC analysis results (Fig. 5), the cutoff value of endocan was 2.18 with an area under the curve (AUC) of $0.870(p<0.0005)$, while the cutoff value of SCUBE-I was
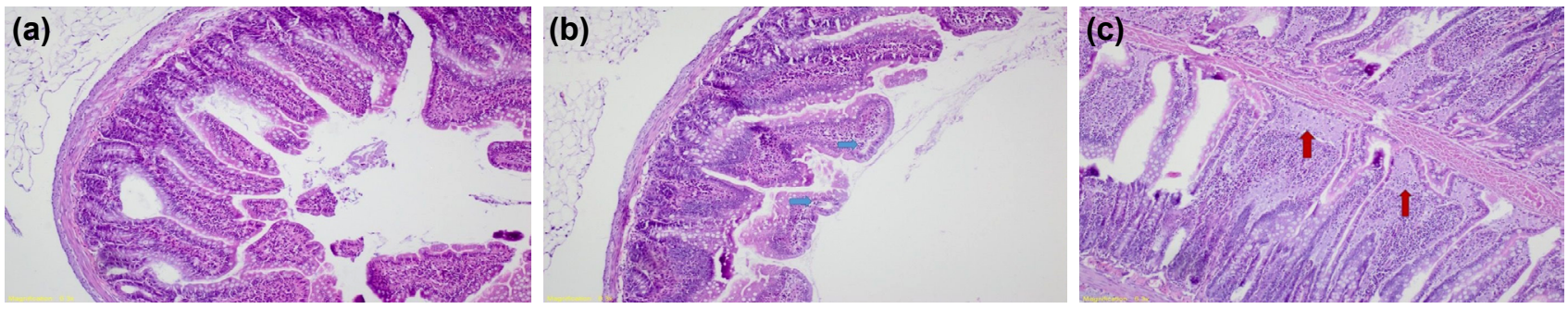

Figure 3. (a) Normal intestinal mucosa in the sham group: Grade 0 (1 $1^{\text {st }}$ Group, $30^{\text {th }}$ minute) $(H \& E ; x 100)$. (b) Almost normal intestinal mucosa, subepithelial spaces at the top of villi (blue arrows): Grade 1 (4 $4^{\text {th }}$ Group ischemia, $30^{\text {th }}$ minute) (H\&E; $\left.x 100\right)$. (c) Subepithelial elevation (red arrow): Grade 2 ( $7^{\text {th }}$ Group reperfusion, $30^{\text {th }}$ minute) $(H \& E ; x 100)$.
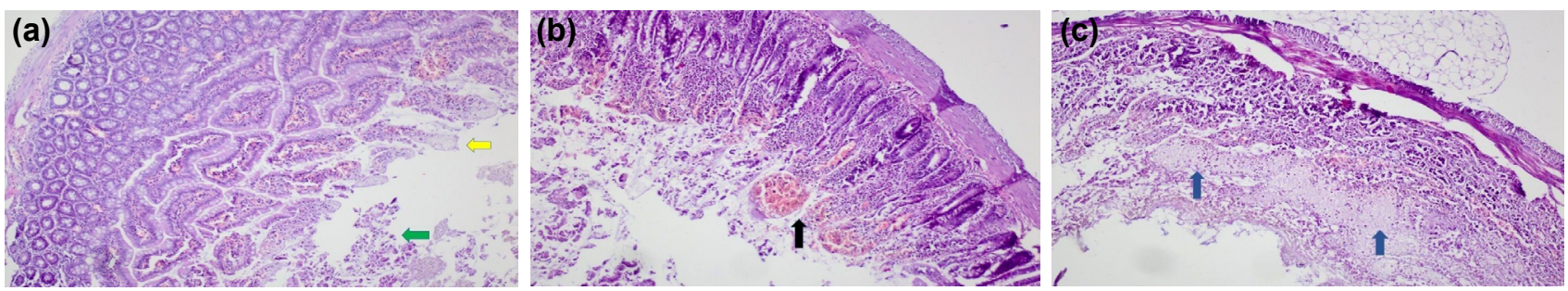

Figure 4. (a) Massive epithelial detachment (green arrow) and a few damaged villi (yellow arrow): Grade 3 ( $8^{\text {th }}$ Group reperfusion, $2^{\text {nd }}$ hour) (H\&E; x100). (b) Damaged villi with dilated capillaries (black arrow): Grade 4 (6 $6^{\text {th }}$ Group ischemia, $5^{\text {th }}$ hour) (H\&E; x100). (c) Disintegration of lamina propria, ulceration, and hemorrhage (blue arrows): Grade 5 ( $6^{\text {th }}$ Group ischemia, $6^{\text {th }}$ hour) $(H \& E ; x 100)$. 


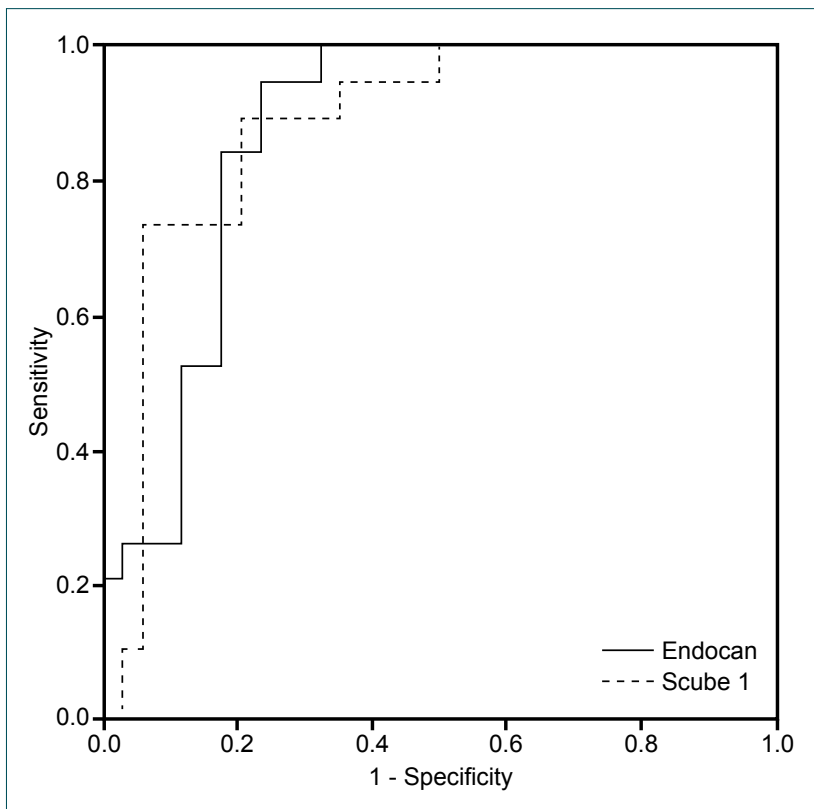

Figure 5. Receiver operating characteristic analysis conducted to find out the power of endocan and SCUBE-1 to determine preparates grouped as reversible and irreversible according to ischemia score. Endocan: Endothelial cell-specific molecule-1; SCUBE-1: Signal peptide-CUB-EGF domain-containing protein 1.

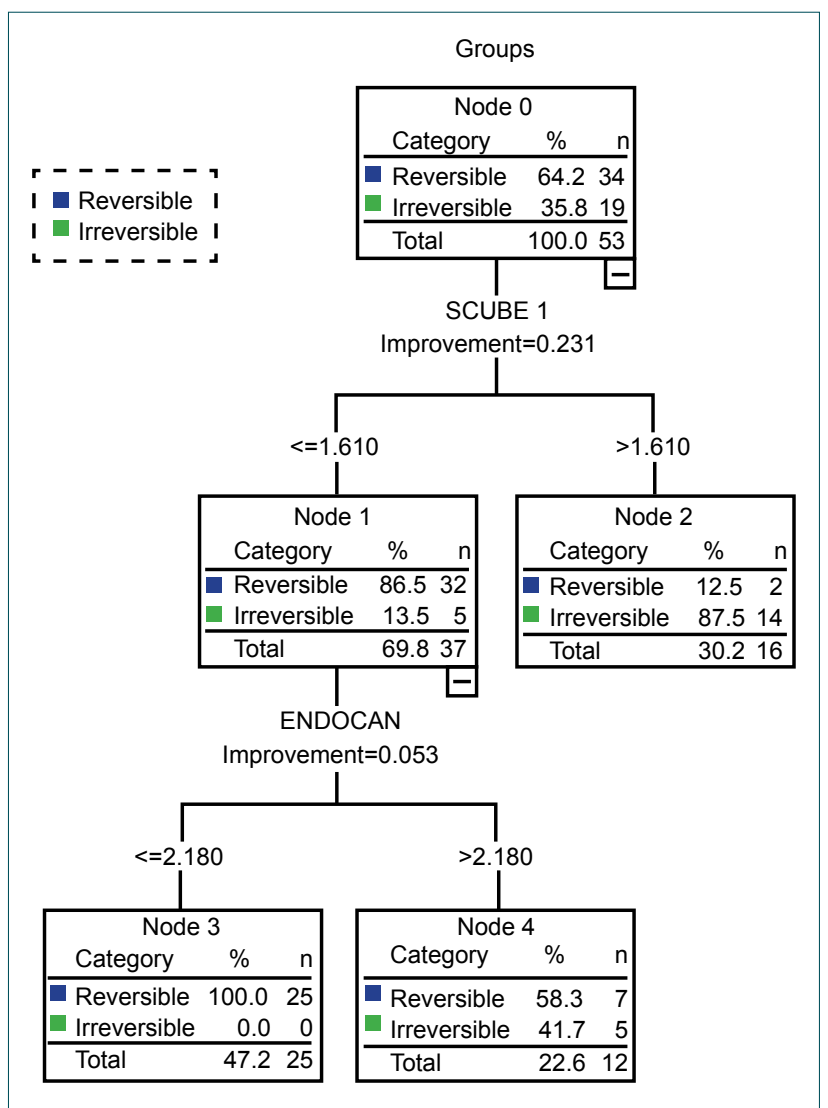

Figure 6. Classification and regression tree analysis of SCUBE-1 and endocan according to Gini index. Endocan: Endothelial cellspecific molecule-1; SCUBE-1: Signal peptide-CUB-EGF domaincontaining protein 1.
I.48 with an AUC of $0.882(p<0.0005)$. The sensitivity and specificity of endocan and SCUBE-I grouped according to cutoff value to distinguish reversible-irreversible were $76.5 \%$ and $94.7 \%$, and $79.4 \%$ and $89.5 \%$, respectively. The +LR and -LR values of endocan and SCUBE-I were 14.43 and 0.24 and 7.56 and 0.22 , respectively.

In CART analysis, the cutoff values of SCUBE-I and endocan were determined to be $1.6 \mathrm{I}$ and 2.18 , respectively, using a Gini index. With this analysis, all 19 preparates could be determined (Fig. 6). When these 2 markers were used together, the sensitivity in distinguishing between reversible and irreversible damage was $94.1 \%$, and the specificity was $73.7 \%$.

\section{DISCUSSION}

Generally, 2 questions occur to a clinician who comes across a case that is thought to be AMI. First, how can I find the correct diagnosis? Second, is it too late for successful therapy? In the literature, different biochemical markers, such as D-lactate, D-dimer, and intestinal fatty acid-binding protein (I-FABP) have been studied to diagnose AMI. ${ }^{[1-13]}$ However, there is still no test that has provided completely satisfying results. SCUBE-I was researched in I study as a predictor in the diagnosis of AMI, but to our knowledge, endocan has not been studied for this purpose. ${ }^{[14]}$

This is the first study to evaluate both markers together and to attempt to determine histopathologically whether they might indicate if the damage that has occurred as a result of AMI is reversible or irreversible. We found that a low level of endocan and elevated SCUBE-I seem to be significant for predicting early mesenteric ischemia and that irreversible intestinal damage can be detected using a combination of SCUBE-I and endocan.

Platelet activation and endothelial damage play a critical role in different stages of AMI. SCUBE-I has been identified in previous studies as a new platelet-endothelial secreted protein, the level of which rises with platelet activation. ${ }^{[1,2]}$

The role of SCUBE-I has been investigated in some ischemic diseases (e.g., acute coronary syndrome, acute ischemic stroke). Dai et al. ${ }^{[2]}$ reported that in acute ischemic stroke and acute coronary syndrome plasma, SCUBE-I concentration was significantly elevated. In addition, Dai et al. ${ }^{\left[{ }^{2]}\right]}$ found that while the plasma SCUBE-I level may not be a sensitive marker for acute stroke and coronary syndrome, it might be a good marker of platelet activation in acute thrombotic disease. Turkmen et al. ${ }^{[14]}$ reported that the SCUBE-I level may be used in the early diagnosis of AMI; however, they noted that further studies are required. They found both histopathological differences at the $30^{\text {th }}$ minute and differences in an ischemia group compared with a sham group in terms of SCUBE-I, but they did not present sensitivity or specificity data. In our study, there were histopathological differences 
at the $30^{\text {th }}$ minute in sham, ischemia, and reperfusion groups; however, there were no differences in SCUBE-I and endocan when compared with the sham group $(p<0.05)$. Differences were present at the second hour in the sham-reperfusion SCUBE-I group, at the sixth hour in the sham-ischemia and sham-reperfusion SCUBE-I groups, and in the sham-ischemia endocan group. Histopathological differences could be observed as early as the $30^{\text {th }}$ minute and significantly measured at the sixth hour. The results of our study are consistent with the results described by Türkmen et al. We also believe that SCUBE-I has the potential to be used as a predictor to demonstrate ischemic harm in AMI at the $30^{\text {th }}$ minute; however, we cannot say that it is completely sufficient to make an early and definitive diagnosis.

In AMI diagnosis studies conducted with d-dimer, lactate, and I-FABP, many sensitivity and specificity values have been found. ${ }^{[15]}$ Various cutoff levels for these markers have been reported. Recognized cutoff levels are needed for markers that may be of use for AMI, such as those already established for other diseases, such as the troponin level in acute myocardial infarction. ${ }^{[16,17]}$

Lactate, the concentration of which can lead to metabolic acidosis, has been investigated as a predictive marker in the diagnosis of ischemia. A study showed that in AMI, lactate was $100 \%$ sensitive and $42 \%$ specific. ${ }^{[18]}$ In another experimental study, when compared with the sham group, there was a significant increase in plasma lactate in the SMA of the mesenteric ischemia group. ${ }^{[18,19]}$ However, Acosta et al. ${ }^{[20]}$ examined patients who were exposed to ischemia for different periods and at different degrees in terms of lactate level and found no statistically significant difference, concluding that lactate levels could not be used as an early diagnostic marker.

Our purpose in adding endocan to SCUBE-I, which is activated by platelet aggregation, was to estimate the condition in the endothelial area. Qui et al. ${ }^{[2]]}$ showed that in patients with acute myocardial infarction, endocan may be used to evaluate endothelial dysfunction. Detecting the endocan level early may be useful in identifying individuals at high risk and thus allowing for early intervention to reduce the prevalence of AMI. Su et al. ${ }^{[22]}$ found that endocan production was significantly increased in the 6-72-hour period. In our study, endocan was significantly elevated in the ischemia group when compared with the sham group at the sixth hour. This demonstrates that, while like SCUBE-I, endocan has the potential to be used as a predictor in determining damage in AMI, because the results take longer to appear than SCUBE-I, it cannot be said to be a completely sufficient marker for an early and definitive diagnosis.

Before starting treatment in AMI patients, knowledge about whether the damage is reversible or irreversible in cases considered for surgical treatment can be a useful guide for the clinician. In our study, the endocan and SCUBE-I +LR and-LR values were 14.43 and 0.24 , and 7.56 and 0.22 , respectively, in the classification of reversible-irreversible groups based on histopathological grading. The correlation coefficient of endocan and SCUBE-I was $0.62(p=0.0005)$. When these 2 markers were evaluated with CART analysis, the $+\mathrm{LR}$ and$L R$ values were 3.16 and 0.08 , respectively. According to this analysis, these markers strongly excluded irreversible cases. All 25 reversible cases of the 53 preparates were identified when an endocan $<2$. 18 cutoff was used with SCUBE-I $<1.61$ (Fig. 6).

The primary limitation of this study is the exclusion of other significant markers. The second limitation is the fact that it was research based on an animal model. Thirdly, hydration, particularly at the sixth hour, may have influenced marker levels.

In conclusion, although we cannot state definitively that they can be used in early diagnosis, the SCUBE-I level appears to have the potential to be an early-stage damage marker in AMI. When SCUBE-I and endocan are studied together according to cutoff values, a reversible-irreversible distinction can be made. However, more extensive studies are needed to fully see the potential practical applications.

\section{Conflict of interest: None declared.}

\section{REFERENCES}

1. Tu CF, Yan YT, Wu SY, Djoko B, Tsai MT, Cheng CJ, et al. Domain and functional analysis of a novel platelet-endothelial cell surface protein, SCUBE1. J Biol Chem 2008;283:12478-88. [CrossRef]

2. Dai DF, Thajeb P, Tu CF, Chiang FT, Chen CH, Yang RB, et al. Plasma concentration of SCUBE1, a novel platelet protein, is elevated in patients with acute coronary syndrome and ischemic stroke. J Am Coll Cardiol 2008;51:2173-80. [CrossRef]

3. Balta S, Mikhailidis DP, Demirkol S, Ozturk C, Kurtoglu E, Demir M, et al. Endocan-a novel inflammatory indicator in newly diagnosed patients with hypertension: a pilot study. Angiology 2014;65:773-7. [CrossRef]

4. Menon P, Kocher ON, Aird WC. Endothelial cell specific molecule-1 (ESM-1), a novel secreted proteoglycan stimulates vascular smooth muscle cell proliferation and migration. Circulation 2011;124:a15455.

5. Aparci M, Isilak Z, Uz O, Yalcin M, Kucuk U. Endocan and endothelial dysfunction. Angiology 2015;66:488-9. [CrossRef]

6. Zhang SM, Zuo L, Zhou Q, Gui SY, Shi R, Wu Q, et al. Expression and distribution of endocan in human tissues. Biotech Histochem 2012;87:172-8. [CrossRef]

7. Oldenburg WA, Lau LL, Rodenberg TJ, Edmonds HJ, Burger CD. Acute mesenteric ischemia: a clinical review. Arch Intern Med 2004;164:105462. [CrossRef]

8. Cho JS, Carr JA, Jacobsen G, Shepard AD, Nypaver TJ, Reddy DJ. Longterm outcome after mesenteric artery reconstruction: a 37-year experience. J Vasc Surg 2002;35:453-60. [CrossRef]

9. Zhao Y, Yin H, Yao C, Deng J, Wang M, Li Z, et al. Management of Acute Mesenteric Ischemia: A Critical Review and Treatment Algorithm. Vasc Endovascular Surg 2016;50:183-92. [CrossRef]

10. Chiu CJ, McArdle AH, Brown R, Scott HJ, Gurd FN. Intestinal mucosal lesion in low-flow states. I. A morphological, hemodynamic, and metabolic reappraisal. Arch Surg 1970;101:478-83. [CrossRef] 
11. Assadian A, Assadian O, Senekowitsch C, Rotter R, Bahrami S, Fürst W, et al. Plasma D-lactate as a potential early marker for colon ischaemia after open aortic reconstruction. Eur J Vasc Endovasc Surg 2006;31:470-4

12. Acosta S, Nilsson TK, Björck M. D-dimer testing in patients with suspected acute thromboembolic occlusion of the superior mesenteric artery. Br J Surg 2004;91:991-4. [CrossRef]

13. Cronk DR, Houseworth TP, Cuadrado DG, Herbert GS, McNutt PM, Azarow KS. Intestinal fatty acid binding protein (i-FABP) for the detection of strangulated mechanical small bowel obstruction. Curr Surg 2006;63:322-5 [CrossRef]

14. Turkmen S, Mentese S, Mentese A, Sumer AU, Saglam K, Yulug E, et al. The Value of Signal Peptide-CUB-EGF Domain-containing Protein 1 and Oxidative Stress Parameters in the Diagnosis of Acute Mesenteric Ischemia. Acad Emerg Med 2013;20:257-64. [CrossRef]

15. Evennett NJ, Petrov MS, Mittal A, Windsor JA. Systematic Review and Pooled Estimates for the Diagnostic Accuracy of Serological Markers for Intestinal Ischemia. World J Surg 2009;33:1374-83. [CrossRef]

16. Bhardwaj A, Truong QA, Peacock WF, Yeo KT, Storrow A, Thomas
S,et al. A multicenter comparison of established and emerging cardiac biomarkers for the diagnostic evaluation of chest pain in the emergency department. Am Heart J 2011;162:276-82. [CrossRef]

17. Baker JO, Reinhold J, Redwood S, Marber MS. Troponins: redefining their limits. Heart 2011;97:447-52. [CrossRef]

18. Lange H, Jäckel R. Usefulness of plasma lactate concentration in the diagnosis of acute abdominal disease. Eur J Surg 1994;160:381-4.

19. Kulacoglu H, Kocaerkek Z, Moran M, Kulah B, Atay C, Kulacoglu S, et al. Diagnostic value of blood $\mathrm{D}$-dimer level in acute mesenteric ischaemia in the rat: an experimental study. Asian J Surg 2005;28:131-5. [CrossRef]

20. Acosta S, Nilsson TK, Malina J, Malina M. L-lactate after embolization of the superior mesenteric artery. J Surg Res 2007;143:320-8 [CrossRef]

21. Qiu CR, Fu Q, Sui J, Zhang Q, Wei P, Wu Y, et al. Serum Endothelial Cel1-Specific Molecule 1 (Endocan) Levels in Patients With Acute Myocardial Infarction and Its Clinical Significance. Angiology 2017;68:354-9.

22. Su YH, Shu KH, Hu CP, Cheng CH, Wu MJ, Yu TM, et al. Serum Endocan Correlated With Stage of Chronic Kidney Disease and Deterioration in Renal Transplant Recipients. Transplant Proc 2014;46:323-7.

\section{DENEYSEL ÇALIŞMA - ÖZET}

\section{Akut mezenterik iskemi hasarının kritik zaman tahmini ve reversibilitesi \\ Dr. Ayhan Aköz,, ${ }^{1}$ Dr. Kenan Ahmet Türkdoğan, ${ }^{1}$ Dr. Nesibe Kahraman Çetin, ${ }^{2}$ Dr. Selen Kum, ${ }^{3}$ \\ Dr. Ali Duman, ${ }^{1}$ Dr. Mevlüt Türe, ${ }^{4}$ Dr. Ahmet Ender Demirkıran ${ }^{5}$}

${ }^{1}$ Adnan Menderes Üniversitesi Tıp Fakültesi, Acil Tıp Anabilim Dalı, Aydın
${ }^{2}$ Adnan Menderes Üniversitesi Tıp Fakültesi, Patoloji Anabilim Dalı, Aydın
${ }^{3}$ Adnan Menderes Üniversitesi Tıp Fakültesi, Histoloji Anabilim Dalı, Aydın
${ }^{4}$ Adnan Menderes Üniversitesi Tıp Fakültesi, Biyoistatistik Anabilim Dalı, Aydın
${ }^{5}$ Adnan Menderes Üniversitesi Tıp Fakültesi, Genel Cerrahi Anabilim Dalı, Aydın

AMAÇ: Bu çalışmada akut mezenterik iskemide yeni iskemik biyobelirteçler olan endocan ve SCUBE-I'in erken evre hasar, tanı ve irreversibıl hasar değerlerini araştırmayı amaçladık.

GEREÇ VE YÖNTEM: Elli dört sıçan ile deneysel bir mezenterik iskemi reperfüzyon modeli tasarlandı. Dokuz grup oluşturuldu: Kan ve doku örneklerinin sadece örneklendiği üç sahte grup [Grup I (30. dakika), IV (2. saat) ve VII (6. saat)]; superior mezenterik arter (SMA) bağlandıktan sonra kan ve doku numuneleri örneklenen üç iskemi grubu [Grup II (30. dakika), V (2. saat) ve VIII (6. saat)]; ve SMA dekompresyonundan sonra kan ve doku numuneleri örneklendirilen ve reperfüzyon bir saat süreyle indüklenen üç reperfüzyon grubu [Grup III (30. dakika), VI (2. saat) ve IX (6. saat)]. SCUBE-I ve endocan için kan örnekleri alındı ve histopatolojik olarak doku örnekleri incelendi.

BULGULAR: SCUBE-I düzeyleri iskemi grubunda sahte gruba göre daha yüksek iken ( $p<0.05)$, geç iskemi (6. saat) grubunda endocan düzeyleri belirgin olarak farklıydı. Bu iki belirteç, histopatolojik incelemeye göre irreversıble mezenterik hasar için birlikte kullanıldığında, reversible-irrreversible hasar ayırımını \%94. I sensitivite, \%73.7 spesifite ile belirledi.

TARTIŞMA: SCUBE-I'in tek başına yükselmesi laboratuvar sıçanlarında erken mezenterik iskemiyi öngörmede önemli olarak gözükmektedir. Bununla birlikte, SCUBE-I ve endocan eş zamanlı kullanımı irreversible bağırsak hasarının tespitinde daha kullanılıslı olabilir.

Anahtar sözcükler: Akut mezenter iskemi; endocan; irreversibilite; SCUBE I.

Ulus Travma Acil Cerrahi Derg 20I8;24(6):507-5I3 doi: 10.5505/tjtes.20।8.697।0 